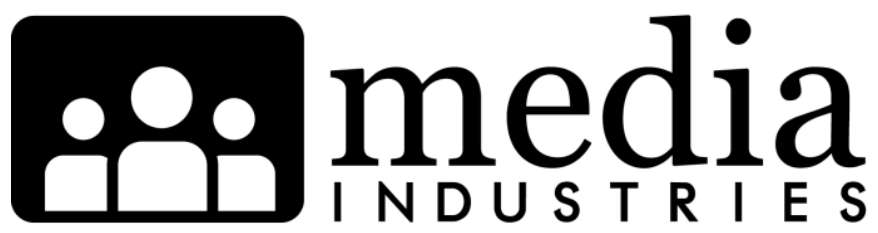

\title{
The Menace of Instrumentalism in Media Industries Research and Education
}

\author{
David Hesmondhalgh' \\ University of Leeds (UK) \\ d.j.hesmondhalgh [AT] leeds.ac.uk
}

\begin{abstract}
:
Media industries research and education are booming. But they face a problem of instrumentalism. Most media industries research takes place outside universities and is commissioned and bought by media companies. Most university media industries research has not been of this kind, but instead claims to be "critical." But the pressures toward instrumentalism in the subfield are growing. This essay explores these pressures and the difficulties facing critical media industries research and education, including "vocationalism" among students. It argues for the importance of distinguishing between knowledge that serves more general flourishing and emancipation, and that which does not. It suggests that research and education oriented primarily to boosting the dividends of shareholders or the salaries of individuals might be less socially valuable than "critical" research, and it advocates collaboration between media industries academics and media workers who understand the value of critical, independent research.
\end{abstract}

Keywords: Education, Research Methods, Scholarly Independence

Media industries research and education are booming. Since hitting a low point of fashionability in the postmodernist and post-Marxist 1990s, media production and media industries research has bounced back. ${ }^{2}$ The most powerful enclaves of social sciencebusiness schools and the economists who often work there-are now paying more attention to the media industries than ever before. Media industries are also a major object of interest for geographers and urban studies analysts concerned with the potential regenerative effects of creative or cultural industries. Those interested in the way that new information technologies have "democratized" cultural production have given an analytical prominence to media industries that they haven't enjoyed for decades. Cultural studies of media production have revivified the intellectual agenda and brought new and talented researchers to the field.

Much of this new wave of research is frustratingly amnesiac about the valuable research that preceded the twenty-first century boom, for example in political economy of media or in sociology of culture. Indeed, researchers working within particular traditions at times 
seem deaf and blind to developments in other fields that also deal with media production. But these problems might in themselves partly be a result of the abundance of media industry studies. This isn't just a matter of laziness or a busy schedule; it's getting harder to keep track of everything.

There is an even greater danger for media industries scholarship and teaching: the menace of instrumentalism. Most media industries research takes place outside universities. Much of it is concerned with quantifying the characteristics and behaviors of audiences, and analyzing change. Much of it is futurological, predicting trends and providing perspectives that might inform the strategy of firms. It is often commissioned or bought by media companies from hundreds of marketing and forecasting firms. And it is usually extremely expensive and closed to public access. University libraries often cannot afford it, let alone ordinary citizens. Some university researchers compete with such organizations to carry out commissioned research.

Most university research on media industries has not been of this instrumentalist kind. Much of it would claim to be critical: of concentration and conglomeration, of international inequality, of poor and unequal labor conditions, of organizational dynamics that lead to content that fails adequately to provide public knowledge or rich aesthetic experiences. However, the pressures towards instrumentalism are growing.

What might we mean by critical? In one of the earliest and most famous contributions to media studies, Paul Lazarsfeld distinguished between critical and administrative communication research. ${ }^{3}$ Lazarsfeld, a major figure in twentieth-century social research, is often cast as villain in a research melodrama, playing the black-hatted positivist against the heroic figures of Theodor Adorno and C. Wright Mills (both of whom he provided with research jobs). ${ }^{4}$ Generations of media educators, who have understandably wanted their students to be questioning rather than compliant subjects, used the distinction as a means to explain the value of critique.

Lazarsfeld, his essay, and the critical/administrative distinction, are more complex than the caricatures make out. The core of his essay considered three objections to administrative research. One, from government and businesses, was against the way in which careful empirical work might produce conclusions that were too qualified and complex to be of practical use. Another, from publicly minded sociologists, was that administrative research is too often directed towards rather small issues, and research should instead be oriented to solving major social problems. A third was that the media are much more complex and diffuse in their influence than administrative research, with its focus on specific aims and problems, had been willing to recognize or able to address. This objection, which had been articulated by a group of fellow German émigrés associated with "critical theory," notably Max Horkheimer and Theodor Adorno, was the main focus of Lazarsfeld's attention in his essay. Critical research, explained Lazarsfeld, required that "the general role of our media of communication in the present social system should be studied." Lazarsfeld was by no means hostile to this viewpoint. Much of his essay was about how insights from critical research (those produced by his colleague Adorno) might enrich empirically oriented communication research, and how empirical work might inform critical theory. ${ }^{5}$

We should be suspicious, then, of simplified and Manichean (good versus evil) distinctions between critical and administrative research. Yet some kind of distinction between knowledge that serves more general flourishing and emancipation, and that which does 
not, seems fundamental to any debate about the value and purpose of research, including media industries research. Arguably, research and education oriented primarily to boosting the dividends of shareholders or the salaries of individuals might be less about such flourishing and emancipation than other types. ${ }^{6}$ Such a conception seems to underpin the perspective of Lazarsfeld, pragmatist though he was.

In addressing such issues, and in many other ways, media industries research and education would benefit from a greater engagement with social theory. As Andrew Sayer has explained, ${ }^{7}$ philosophical reconstructions of critical social science often emphasize four elements: the identification of problems (false beliefs, suffering, unmet needs, etc.); identification of the causes or sources of those problems, such as forms of domination; negative appraisals of those sources; and approval of actions which reduce or remove those sources. Such a critical social science is most likely to be cogent, coherent, and effective when it addresses normative questions of good and bad, right and wrong, rather than dismissing explicit ethical discourse as Enlightenment will-to-power (as many postmodernists have), or as an unscientific failure to bracket questions of value (as many positivists do). And media industries research informed by a critical social science perspective would involve explanation as well as evaluation. Often both are missing from research that aspires to be, or merely "feels," critical. Some "critical" researchers seem to think that the first stage of critical social science, the identification of problems, is moot, because, in their view, social media and other features of the digital world will resolve most problems anyway. In the work of some other researchers, it is conceptually far from clear what the problems, sources, and alternatives are meant to be.

In a twenty-first century context where universities are increasingly encouraged to service the requirements of governments and businesses, and to find alternative sources of funding beyond student fees and public research money, the specter of instrumentalism looms larger than ever over all research. Few would doubt that recent times have seen an erosion of the Humboldtian vision of the university as a free space centered on the Enlightenment goal that knowledge should ultimately serve social emancipation. That vision and that goal were always compromised by domination and privilege. But their erosion is deeply problematic. A number of factors have contributed to this decline. Attacks on elitism and paternalism have been appropriated and have served to undermine the legitimacy of universities and of (in the broadest sense) scientific knowledge. In an era when private businesses are often dubiously presented as more efficient than public organizations, universities are being pushed in the direction of marketization, promotionalism, and instrumentalism. In an effort to protect research funding in the social sciences and humanities, research councils have increasingly been influenced by the agendas of their political paymasters. ${ }^{8}$

Another push in the direction of instrumentalism is the pressure for academic researchers to accumulate professional capital. Only a saint would have no interest in success; but as Craig Calhoun has pointed out, to the extent that researchers involve themselves in such accumulation they are

encouraged to accept commonplace understandings of the world. To challenge these too deeply would be to court detachment from those whose "purchase" of their products enables them to accumulate capital...In the 
spirit of professionalism they betray the calling truly and openly to explore the world. ${ }^{9}$

When many university managers and workers today have an uncertain grasp of the value of the autonomy of their own institutions, it is hardly surprising that others struggle to affirm the legitimacy of those institutions, or appreciate their potential social and cultural contributions.

These problems take a specific form when it comes to media industries research. Many media professionals share a more general distrust of "fusty" academics. Some adopt robust entrepreneurial attitudes and are not shy in saying that academics should be willing to provide directly useful services to them-preferably for free, or subsidized by the public purse. Because the media industries themselves are major producers of knowledge, ideas, and commentary, arguably professionals from these industries are even more inclined to question the value of autonomous research oriented towards emancipation than those working in other sectors. After all, such professionals are in competition with universities. This makes genuine and open collaboration between media workers and academics all the more valuable, and there undoubtedly should be a place for such collaboration alongside independent research. Media professionals who have an understanding of the value of autonomous, independent research can be a joy to work with. But collaborative research still needs to be judged by scientific principles of rigor, originality, and significance, rather than on the basis of whether it contributes to economic prosperity within a particular company, country, or region.

A separate but related problem for media industries research is instrumentalism among students. Many look to media industries education for an entry into what appears to be a desirable form of work. Given the difficulties for teachers, inside and outside universities, in articulating the value of knowledge and learning, it is hardly surprising that some students seek vocationalist forms of education, and underappreciate open inquiry. Some of these students seem to seek a certain notion of a business school approach to media industries, based on the secrets of media management.

I strongly believe it is possible to give students exposure to media production practices, and an understanding of media management, while emphasizing that media degrees might also have a higher purpose: to provide symbol makers and creative managers with an education that encourages them to live good lives, and to contribute to the flourishing of their fellow citizens. Our main purpose as teachers, and as researchers, should not be to help young people accumulate educational and cultural capital, or to provide training so that the media industries don't have to. It should be to build and share critical understandings of how media industries shape public knowledge and aesthetic experience. To achieve this will mean confronting the menace of instrumentalism.

1 David Hesmondhalgh is Professor of Media in the Institute of Communications Studies (soon to be renamed the School of Media and Communication) at the University of Leeds. He is the author of Why Music Matters (Blackwell, 2013), Creative Labour: Media Work in Three Cultural Industries (Routledge, 2011, co-written with Sarah Baker), and The Cultural Industries, now in its third edition (Sage, 2012). $\mathrm{He}$ is also editor or co-editor of five other books. He recently co-edited (with 
Anamik Saha) a special issue of the journal Popular Communication on "Race, Ethnicity and Cultural Production."

2 See David Hesmondhalgh, "Politics, Theory and Method in Media Industries Research," in Media Industries: History, Theory, Method, eds. Jennifer Holt and Alisa Perren (Malden, MA and Oxford: Wiley-Blackwell, 2009), 245-55; David Hesmondhalgh, The Cultural Industries, 3rd edition (London and Los Angeles: Sage Publications, 2013), chap. 1.

3 Paul Felix Lazarsfeld, "Remarks on Administrative and Critical Communications Research," Studies in Philosophy and Social Science 9 (1941): 2-16.

4 C. Wright Mills' later dismissal of Lazarsfeld's "abstracted empiricism" in The Sociological Imagination (New York: Oxford University Press, 1959) cemented Lazarsfeld's role as the bad guy in the critical-versus-administrative soap opera. See Jonathan Sterne's essay "C. Wright Mills, The Bureau for Applied Social Research, and the Meaning of Critical Scholarship," Cultural Studies/Critical Methodologies 5(1) (2005): 65-94.

5 Lazarsfeld's essay leaves major problems concerning administrative research untouched: how to fund research, and how funding might affect research.

6 Of course this makes all knowledge "instrumental" in the broadest sense: The term "instrumentalist" is intended here to draw attention to "bad" instrumentality that favours the flourishing of the few over the many, and/or inhibits collective flourishing.

7 Andrew Sayer, Realism and Social Science (London: Sage, 2000), 159.

8 See Allison Hearn, "'Through the Looking Glass': The Promotional University 2.0," in Blowing Up the Brand, eds. Melissa Aronczyk and Devon Powers (New York: Peter Lang, 2010), 195-218.

9 Craig Calhoun, Critical Social Theory (Oxford: Blackwell, 1995), 2.

\section{Bibliography}

Calhoun, Craig. Critical Social Theory. Oxford: Blackwell, 1995.

Hearn, Allison. "'Through the Looking Glass': The Promotional University 2.0." In Blowing Up the Brand, edited by Melissa Aronczyk and Devon Powers, 195-218. New York: Peter Lang, 2010.

Hesmondhalgh, David. "Politics, Theory and Method in Media Industries Research." In Media Industries: History, Theory, Method, edited by Jennifer Holt and Alisa Perren, 245-255. Malden, MA and Oxford: Wiley-Blackwell, 2009.

Hesmondhalgh, David. The Cultural Industries, 3rd edition. London and Los Angeles: Sage Publications, 2013.

Lazarsfeld, Paul. "Remarks on Administrative and Critical Communications Research." Studies in Philosophy and Social Science 9 (1941): 2-16.

Mills, C. Wright. The Sociological Imagination. New York: Oxford University Press, 1959.

Sayer, Andrew. Realism and Social Science. London: Sage, 2000. 
Sterne, Jonathan. "C. Wright Mills, The Bureau for Applied Social Research, and the Meaning of Critical Scholarship." Cultural Studies/Critical Methodologies 5(1) (2005): 65-94.

\section{(cc) Br-NC-ND}

Copyright (C) 2014 (David Hesmondhalgh). Media Industries is and open-access, peer-reviewed, online academic journal. As such, we aim to participate in the open exchange of information. This work is licensed under a Creative Commons Attribution Noncommercial No Derivatives (by-nc-nd) License. Under this license, this work is available for sharing and noncommercial distribution provided the appropriate attribution is given. 